\title{
ARGUMEN ISLAM TENTANG ANTI RADIKALISME
}

\author{
Zulkifli M. Nuh \\ Fakultas Tarbiyah dan Keguruan UIN Suska Riau \\ e-mail: kamp_ountung@yahoo.co.id
}

\begin{abstract}
Abstrak
Diskursus radikalisme dalam studi agama bukanlah merupakan sesuatu hal yang baru, akan tetapi menjadi aktual terutama sejak peristiwa penyerangan Twin Towers World Trade Centre (WTC) dan gedung Pentagon di New York, Amerika Serikat pada tanggal 11 September 2001(September Kelabu). Tulisan ini menguraikan beberapa argumentasi Islam, terkait dengan radikalisme. Setidaknya ada empat dasar yang menjadi argumen Islam tentang radikalisme ini, Pertama, kesatuan dalam aspek keTuhanan dan pesan-Nya (wahyu); Kedua, kesatuan kenabian; Ketiga, tidak ada paksaan dalam beragama; dan Keempat, pengakuan terhadap eksistensi agama lain.
\end{abstract}

Keywords: radikalisme, Islam,

\section{Pendahuluan}

Diskursus terorisme di dunia bukanlah merupakan sesuatu hal yang baru, akan tetapi menjadi aktual terutama sejak peristiwa penyerangan Twin Towers World Trade Centre (WTC) dan gedung Pentagon di New York, Amerika Serikat pada tanggal 11 September 2001(September Kelabu), yang memakan tidak kurang dari 3000 korban (Aziz, 2010:122).

Menariknya, aksi terorisme tersebut dilakukan melalui serangan udara, tidak menggunakan pesawat tempur, melainkan menggunakan pesawat komersil milik perusahaan Amerika sendiri, sehingga tidak tertangkap oleh radar Amerika Serikat (Aziz, 2010:122).
Peristiwa tersebut mengawali babak baru percaturan politik dunia, setidaknya pasca runtuhnya tembok berlin di Jerman Timur dekade 90-an sebagai tanda berakhirnya perang dingin yang melibatkan antara Amerika Serikat (AS) dan Uni Soviet. Terorisme kemudian menjelma menjadi isu global yang mempengaruhi kebijakan politik seluruh negara-negara di dunia, sehingga menjadi titik tolak persepsi untuk memerangi terorisme sebagai musuh internasional.

Kejahatan yang mengakibatkan pembunuhan massal tersebut telah mempersatukan dunia melawan Terorisme Internasional. Tidak terkecuali Indonesia yang merupakan bagian dari salah satu 
Negara di Asia yang pro aktif dengan kebijakan politik anti terorisme.

Kebijakan politik anti - terorisme di Indonesia, dilatarbelakangi oleh rentetan peristiwa yang berujung pada prilaku teror. Tragedi bom Bali I (12/10/2002) menjadi bagian dari rangkaian terorisme di Indonesia. Insiden tersebut menimbulkan korban sipil terbesar di dunia, yaitu 184 orang tewas dan melukai lebih dari 300 orang, dan merupakan babak awal terorisme di Indonesia.

Sebelumnya, Indonesia juga sudah diguncang dengan berbagai ledakan di belahan nusantara, antara lain; Plaza Hayam Wuruk (15/4/1999), Masjid Istiqlal (19/4/1999), Kejaksaan Agung (4/6/2000), Kedubes Filipina Jakarta (3/8/2000), Bursa Efek Jakarta (13/9/2000), serangkaian bom natal di Jakarta, Bekasi, Sukabumi, Mataram, Pematangsiantar, Medan, Batam dan Pekanbaru (24/12/2000), Gereja Santa Anna dan Huria Kristen Batak Protestan (HKBP) Jakarta (22/7/2001), Gereja Bethel Tabernakel Kristus Alfa Omega Semarang (31/7/2001), Plaza Atrium Jakarta (23/9/2001), Australian International School (AIS) Jakarta (6/11/2001), Restoran KFC Makassar (12/10/2001) (Abimanyu, 2006:83-90).

Terlebih lagi dengan diikuti terjadinya deretan insiden yang sama di beberapa wilayah meskipun dengan frekuwensi yang berbeda. Mulai dari tragedi Ambon, Maluku, Aceh dan bahkan kejadian yang tidak kalah dahsyatnya dan mungkin masih terngiang di ingatan yaitu pemboman Hotel JW Marriot dan Hotel Ritz Charlton pada 17 Juli 2009 yang menewaskan 9 orang 42 orang cedera menguatkan kebenaran idiom "Indonesia sarang teroris" (Tempo, 2011).

Selain berimbas terhadap perekonomian bangsa, beberapa peristiwa di atas, mampu mengantarkan Indonesia mendapatkan stigma negatif sebagai bagian dari negara teroris di mata dunia. Satu pertanyaan yang muncul kala itu, siapa aktor intelektual dibalik peristiwa berdarah tersebut? Berbagai pendapat pun mengemuka, mulai anggapan skenario Amerika, misi Australia menguasai Indonesia, bahkan sempat muncul pula anggapan bahwa Inteligen dan TNI berada di balik aksi teror bom itu. Hingga ditemukan fakta bahwa pelaku sekaligus dalang bom bunuh diri adalah kelompok teroris Jamaah Islamiyah.

Menyadari sedemikian besarnya kerugian yang ditimbulkan dari Terorisme dan dampak yang dirasakan secara langsung oleh Indonesia sebagai akibat dari terorisme, pihak yang berwenang bergagas memburu dan menangkap aktor intelektual yang ada dibalik aksi terorisme, dengan membentuk Detasemen Khusus 88 Antiteror (Densus). Penangkapan dan penyergapan berkali-kali dilakukan, namun alih-alih berhenti, terorisme sampai hari ini masih menjadi ancaman dan bahkan mengalami perkembangan yang luar biasa. 
Uraian fenomena terorisme di atas menggambarkan betapa akut dan suburnya terorisme di Indonesia. Realitas ini menarik untuk dikaji, karena suburnya terorisme bersamaan dengan realitas Indonesia yang sebagian besar masyarakatnya memeluk agama Islam. Tak pelak lagi dari sekian deretan aksi kekerasan dan aksi terorisme di negeri ini, pelakunya tidak lain adalah kalangan muslim, lantas apa hubungan antara terorisme dengan agama?.

Secara normative, agama dan terorisme barangkali tidak memiliki keterkaitan sama sekali. Tetapi jika lihat secara empiris, benang merah diantara keduanya memang tidak bisa dielakkan. Hal ini tidak lepas dari fakta bahwa banyak aksi-aksi terorisme, sebagaimana diulas di atas, yang mengatasnamakan agama, kalau tidak bersumber pada ajaran agama. Temuan Prof. Wilkinson dari The Terorism Research Center CSIS (1995), dari hasil study di beberapa daerah tentang motivasi dan penyebab terorisme menyebutkan bahwasanya terorisme bersumber dan berakar dari kelompok-kelompok Islam fundamental yang hampir pasti ada disetiap Negara-negara Islam (Witdarmono, 2002). Harus diakui bahwa tindakan terorisme seperti halnya bom bunuh diri merupakan tindakan yang luar biasa, untuk bisa melakukan tindakan yang luar biasa tersebut tentunya dalam diri pelaku didasarkan oleh suatu latar belakang yang luar biasa pula, paling tidak adanya suatu ideology yang tertanam kuat dalam mereka. Beground ideologi tertentu yang tertanam dengan kuat dan mengakar dalam pelaku menentukan gerak dan tindakan pelaku terorisme.

Mengutip tulisan $H$. Witdarmono dalam artikel yang dimuat kompas yang berjudul 'teror dalam 'benak' agama (wacana agama dalam terorisme)";

"Terorisme juga tidak lepas dari munculnya faham fundamintalisme agama. Secara historis istilah fundamintalisme awalnya dikenal dilakangan Kristen, istilah tersebut merupakan sebuah sistem religius dan intelektual yang bertumpu pada inerrancy dan infallibility dalam memahami alkitab. Sedangkan di dalam Islam, fundamentalisme pertama-tama lebih bersifat gerakan social yang mengambil bentuk keagamaan. Umumnya, fundamentalisme Islam merujuk pada empat hal: pertama, pembaharuan. Kedua, reaksi pada kaum modernis. Ketiga, reaksi pada westernisasi. Keempat, keyakinan terhadap Islam sebagai ideology alternative" (Witdarmono, 2002).

Jika disederhanakan. Ada dua variable penjelas utama untuk memahami relasi dan munculnya gerakan-gerakan fundamentalisme dan terorisme di kalangan Islam. Pertama, faktor internal. Kedua, faktor eksternal. Penjelasan yang pertama bahwasanya lahirnya terorisme banyak berkaitan dengan penafsiran konsep jihad, yang dipahami oleh sebagian penganut Islam dengan paradigma literal. Literalisme identik dengan pemahaman yang kaku dan ektrim, paradigma ini juga telah menjadi 
inspirasi atas tumbuhnya wahabisme yang di motori oleh 'Abdul Wahab. Mereka memahami teks-teks agama sebagai sebuah corpus tertutup, dalam artian mereka menilai kebenaran sebatas dengan apa yang ada pada dirinya, konsekwensinya mereka tidak mengakui cara pembacaan selain pembacaan secara harfiah a la pemahaman mereka. Bukti bahwa wahabisme merupakan bentuk dari sebuah pemahaman yang mengarah pada terorisme sebagaimana yang kami maksud, ini terlihat pada tahun 1159 H/1746 M, wahabi melakukan proklamasi formal jihad melawan semua orang yang tidak sejalan dengan pemahaman tauhid ala wahabisme karena orang-orang tersebut dianggap sebagai golongan kafir, musyrik, dan murtad (Algar, 2013:90.

Implikasinya adalah mereka selalu melihat dunia dalam dua kacamata (binner opposition). Yaitu, dâr al-barb (negeri non muslim, kafir, syirik atau perang) dan dâr al Islâm (negeri Islam ). Daerah yang dianggap dâr al- harbi dipandang sebagai sasaran ekpansi dan penundukan. Disilah jihad dijadikan sebagai slogan mobilisasi yang menghadirkan Islam dengan wajah yang menakutkan (teror) (Asfar, 2003:67).

Pada sisi yang lain, munculnya terorisme juga dipicu oleh faktor ekternal. Dalam artian, terorisme muncul merupakan bentuk reaksi terhadap hadirnya modernisasi yang dilakukan oleh Barat terhadap dunia Islam. Kehadiran modernisasi beserta isme-ismenya dipahami sebagai ancaman dan mendistorsi otoritas agama tradisional mereka. Belum lagi ketika modernism beserta isme-ismenya "modernism, liberalism dan humanism" dianggap gagal memberikan solusi yang lebih baik maka arus terorisme akan semakin menguat (Asfar, 2003:67).

Agama sebagai ajaran hadir dalam kehidupan manusia telah dipersepsikan dan dipahami secara beranekaragam. Dan sebagai sistem makna, agama memiliki dua fungsi pokok dalam kehidupan individu maupun social, yaitu regulasi dan justifikasi. Agama sebagai regulasi berarti sebagai patron of value, oleh karenanya, agama diposisikan sebagai pemberi arahan-arahan dari apa yang boleh dilakukan, harus dilakukan dan yang tidak boleh dilakukan. Agama menjadi acuan sumber perilaku baik yang bersifat spritualistik ataupun yang matrelialistik (bersifat duniawi maupun ukhrawi). Pada penjelasan yang kedua, agama sebagai justifikasi berarti, agama berfungsi sebagai landasan moral dari sebuah tindakan pelaku (Lauba, 1912:5).

Dari penjelasan tersebut bisa dipahami bahwa agama merupakan basis nilai yang paling fundamental dan universal. Kembali pada pertanyaan di atas, apa hubungan agama dan terorisme? kalau berangkat dari penjelasan di atas, setidaknya ada dua kemungkinan hubungan antara terorisme dengan agama. Pertama, agama menjadi sumber dari terorisme apabila tindakan teror itu merupakan perwujudan dari perintah 
agama, baik secara langsung maupun tidak langsung. Yang demikian, biasanya terjadi akibat dari pemahaman atas ajaran agama secara leterlek (tekstual). Kedua, hubungan antara agama dan terorisme bisa berlangsung secara koinsiden, dimana agama bukan merupakan sebab melainkan digunakan untuk menciptakan muatan moral terhadap tindakan tersebut. Dengan artian agama menjadi penopang dan menjadi pembenaran dari kepentingan pelaku, ini merupakan konsekwensi logis dari agama sebagai sistem nilai yang universal.

Pemahaman atas agama secara radikal dan distorsif (ideologi teroris) semakin menjadi bahaya laten yang terus merongrong pola pikir dan pola sikap generasi bangsa Indonesia. Hal itu sangat beralasan, jika melihat fakta tragedi bom JW Marriott yang kedua kalinya pada beberapa waktu yang lalu, dengan pelaku bom bunuh diri (suicide, bomber) bernama Dani Dwi Permana yang diketahui masih berusia remaja. Dengan bungkus semangat jihad di jalan Allah (jihâd fi sabîlillâh), rupanya para teroris sengaja membidik para remaja untuk memuluskan agendanya.

Di tangan teroris, Islam yang semula merupakan kepercayaan open minded dan inklusif yang mengajarkan kedamaian (rahmatan lil âlamîn), digeser ke arah intepretasi teks keagamaan yang berdimensi sosial-politik. Hal inilah yang menyebabkan agama Islam dihadirkan dengan wajah yang menakutkan bagi kehidupan politik dan tidak menawarkan ajaran-ajaran universal. Akibatnya Islam yang pada mulanya merupakan agama yang serba meliputi, menjadi tereduksi fungsinya sebagai ideologi gerakan politik dan digunakan sebatas sebagai langkah pembelaan kelompok-kelompok muslim parsial.

\section{Makna Radikalisme}

Radikal berasal dari bahasa latin radix yang artinya akar. Dalam bahasa Inggris kata radical dapat bermakna ekstrim, menyeluruh, fanatik, revolusioner, ultra dan fundamental (Hornby, 2000:691). Sedangkan menurut John M. Echol dan Hassan Shadily (1996) Radicalism berasal dari kata radical yang berarti akar.

Secara istilah, Radicalism artinya doktrin atau praktik penganut paham radikal atau paham ekstrim (Nuh, 2009). Dalam Kamus Besar Bahasa Indonesia (2002:919), radikalisme diartikan sebagai paham atau aliran yang menginginkan perubahan dengan cara keras atau drastis. Dalam pengertian yang lain perubahan yang cenderung menggunakan kekerasan atau gerakan yang berpandangan kolot dan sering menggunakan kekerasan dalam mengajarkan keyakinan mereka.

Sementara Sartono Kartodirdjo (1985:38) mengartikan radikalisme sebagai gerakan sosial yang menolak secara menyeluruh tertib sosial yang sedang berlangsung dan ditandai oleh kejengkelan moral yang kuat untuk menentang dan 
bermusuhan dengan kaum yang memiliki hak-hak istimewa dan yang berkuasa.

Radikalisme sering dimaknai berbeda diantara kelompok kepentingan. Dalam lingkup keagamaan, radikalisme merupakan gerakan-gerakan keagamaan yang berusaha merombak secara total tatanan sosial dan politik yang ada dengan jalan menggunakan kekerasan (Ruabaidi, 2007:33).

Sedangkan dalam studi Ilmu Sosial, Radikalisme diartikan sebagai pandangan yang ingin melakukan perubahan yang mendasar sesuai dengan interpretasinya terhadap realitas social atau ideologi yang dianutnya (Hasani dan Naipospos, 2010:19)

Dengan demikian, radikalisme merupakan gejala umum yang bisa terjadi dalam suatu masyarakat dengan motif beragam, baik sosial, politik, budaya maupun agama, yang ditandai oleh tindakan-tindakan keras, ekstrim, dan anarkis sebagai wujud penolakan terhadap gejala yang dihadapi.

Dari perspektif bahasa, sebenarnya radikal jauh berbeda dengan teroris. Sebab, radikal adalah proses secara sungguh-sungguh untuk melatih keberhasilan atau cita-cita yang dilakukan dengan cara-cara yang positif. Sementara itu, terorisme berasal dari kata teror yang bermakna menakut-nakuti pihak lain. Oleh sebab itu, teror selalu dilakukan dengan cara-cara negatif dan menakutkan pihak lain. Seiring dengan dinamika dan pola gerakan kelompok-kelompok di masyarakat, akhirnya antara radikal dan teror menjadi satu makna, yaitu radikal merupakan embrio dari gerakan teror. Jika memiliki pola-pikir radikal, maka berpeluang besar untuk melahirkan aksi teror.

Kata atau istilah radikalisme memiliki makna yang sejenis seperti istilah militan, garis keras, dan fundamentalisme. Pengertian militan kalau merujuk kepada kamus bahasa Inggris Collin Cobuild, English Dictionary for Advanced Learners (2001:997), bermakna seseorang atau suatu sikap yang sangat percaya pada sesuatu dan aktif mewujudkannya dalam perubahan sosial politik. Bahkan cara-cara yang digunakan sering bersifat ekstrim dan tidak bisa diterima oleh orang lain.

Sedangkan Kamus Besar Bahasa Indonesia mendefinisikan bahwa arti militant adalah bersemangat tinggi, penuh gairah, atau berhaluan keras (1990:583)

Istilah lain dari radikalisme ini adalah fundamentalisme. Kata "fundamental" dalam Kamus Besar Bahasa Indonesia (1990:245) merupakan kata sifat yang memberikan pengertian "bersifat dasar (pokok), mendasar", diambil dari kata "fundament" yang berarti "dasar, asas, alas, fondasi". Dengan demikian, fundamentalisme dapat diartikan sebagai paham yang berusaha memperjuangkan atau menerapkan apa yang dianggap mendasar. 
Istilah fundamentalisme, menurut Azra (1996:107), sebetulnya relative baru dalam kamus peristilahan Islam. Secara historis, istilah ini muncul pertama dan populer di kalangan tradisi Barat-Kristen. Namun demikian, bukan berarti dalam Islam tidak dijumpai istilah atau tindakan yang mirip dengan fundamentalisme yang ada di Barat. Pelacakan historis gerakan fundamentalisme awal dalam Islam bisa dirujukkan kepada gerakan Khawarij, sedangkan representasi gerakan fundamentalisme modern bisa dialamatkan kepada gerakan Wahabi Arab Saudi dan Revolusi Islam Iran.

Penyebutan istilah radikalisme dalam tinjauan sosio-historis pada awalnya dipergunakan dalam kajian sosial budaya dan dalam perkembangan selanjutnyanya istilah tersebut dikaitkan dengan persoalan politik dan agama. Istilah radikalisme merupakan konsep yang akrab dalam kajian keilmuan sosial, politik dan sejarah. Istilah radikalisme digunakan untuk menjelaskan fenomena sosial dalam suatu masyarakat atau Negara (Effendi, 1998).

Adapun yang dimaskud kelompok Islam radikal menurut Jamhari dan Jajang Jahroni (2004:2-3) adalah kelompok yang mempunyai keyakinan idiologis tinggi dan fanatik yang mereka perjuangkan untuk menggantikan tatanan nilai dan sistem yang sedang berlangsung.

Menurut Qardawi (2004:4-5), dapat diidentifkasi beberapa landasan idiologis yang dijumpai dalam gerakan Islam radikal. Pertama, kelompok ini berpendapat bahwa Islam adalah agama yang komprehensif. Kedua, ideologi masyarakat Barat yang sekuler dan materialistik harus ditolak kalau masyarakat mencontoh ideologi Barat berarti masyarakat muslim tidak berhasil karena ideologi masyarakat Barat bukan ideologi yang ideal menurut ajaran Islam. Ketiga, Perubahan sosial yang diinginkan oleh masyarakat Islam adalah perubahaan sosial yang berlandaskan pada sumber hokum Islam yang utama yaitu Al-Quran dan Al-Hadist. Keempat, idiologi Barat harus ditolak, oleh karena itu masyarakat muslim harus menegakkan hukum Islam. Kelima, kelompok ini memberlakukan system sosial dan hukum yang sesuai dengan ajaran yang dibawa nabi Muhammad SAW, dan menolak ideology Barat tetapi sebenarnya kelompok ini tidak menolak moderenisasi. Moderenisasi dalam bidang sains dan teknologi diterima asal tidak bertentangan dengan ajaran Islam. Keenam, mereka berkeyakinan bahwa upaya-upaya Islamisasi pada masyarakat muslim tidak akan berhasil tanpa menekankan aspek pengorganisasian pada masyarakat ataupun pembentukan sebuah kelompok yang kuat.

Selain itu dengan menyakinkan pengikutnya untuk menjalankan tugas suci keagamaan dalam rangka menegakkan hukum Islam. Gerakan Islam radikal telah memberikan warna berbeda bagi perjalanan corak keberagamaan di Indonesia. Misalnya, dalam pengalaman 
umat Islam, terjadi polarisasi yang sangat tajam antar Islam moderat dan Islam radikal di masa sekarang. Setelah Islam moderat berhasil mendapatkan tempat di hati penguasa sejak 1980-an, kini di era reformasi, mereka mendapat tantangan serius dari gerakan Islam radikal yang menyeruak ke dalam lapisan sosial masyarakat. Mereka berhasil merebut simpati public secara terbatas dengan membangun opini publik dan organisasi gerakan. Tak heran jika suara mereka di pentas nasional begitu nyaring terdengar.

Karena itu, perkembangan radikalisme Islam di Indonesia merupakan suatu kenyataan sosio-historis dalam negara majemuk, tetapi juga bisa menjadi ancaman bagi masa depan pluralisme di Indonesia. Sebagai antisipasi, perlu memeperluas gerakan islam yang moderat, pluralis, dan inklusif di tengahtengah masyarakat.

Gagasan globalisasi dan modernitas didasarkan pada dua hal. Pertama, secara diskursif, gerakan moderasi umat diyakini sebagai penopang terciptanya harmonisasi sosial masyarakat di era mulikultural. Karena multikulturalisme merupakan realitas historis dalam masyarakat yang mesti disikapi secara positif. Dengan demikian, ekslusivitas beragama diyakini secara total sebagai kebenaran agama (religious truth) bisa menjadi batu sandungan ideologis untuk memecahkan problem pluralisme di Indonesia. Itu sebabnya pendidikan pluralis menjadi prioritas dalam menjembatani doktrin ekslusif. Kedua, secara praksis, praktek kehidupan beragama masih mendikotomi klaim kebenaran dan keselamatan dalam masing-masing umat beragama mesti dikikis.

Menurut Yusuf Qardawi (2009:35), term radikal ini dapat dipahami dalam dua jenis yang berbeda, radikal kiri dan radikal kanan. Dalam pandangannya, makna kata radikal yang sebenarnya bermakna positif, kini sudah mengalami pergeseran makna.

Jika mau mengikuti definisi yang dibuat oleh Jamhari dan Jahroni (2004:2-4), maka Islam radikal mengacu kepada "kelompok yang mempunyai keyakinan ideologis tinggi dan fanatik yang mereka perjuangkan untuk menggantikan tatanan nilai dan system yang sedang berlangsung."

Sementara bagi Abdurrahman Mas'ud (2017), kelompok radikalisme itu merujuk pada mereka yang memiliki ciri-ciri 1). Memperjuangkan Islam secara kaffah, menjadikan syrai'at Islam sebagai hukum negara, 2). Mendasarkan praktek keagamaannya pada orientasi masa lalu (salafy), 3). Cenderung memusuhi Barat, terutama sekularisme dan dan modernisme, 4). Perlawanan terhadap liberalisme Islam yang tengah berkembang di Indonesia.

Radikalisme sendiri dapat ditandai dengan beberapa indikator radikal sebagaimana disampaikan Qardhawi (2009:40-55); Pertama, adalah fanatisme terhadap satu pendapat tanpa mengakui 
adanya pendapat lain, Kedua, mewajibkan orang lain untuk melaksanakan apa yang tidak diwajibkan oleh Allāh Swt., Ketiga, sikap keras dan kasar yang terkadang tidak pada tempatnya, Keempat, berprasangka buruk terhadap orang lain dan Kelima, Radikalisme ini mencapai puncaknya ketika mulai mengafirkan dan menuduh manusia lain sudah murtad dari Islam.

Pendapat lain menyebutkan bahwa ciriciri mereka yang memiliki pemahaman agama radikal antara lain (Masduqi: 2012, 3) Pertama sering mengklaim kebenaran tunggal dan menyesatkan kelompok lain yang tak sependapat. Klaim kebenaran selalu muncul dari kalangan yang seakanakan mereka adalah Nabi yang tak pernah melakukan kesalahan ma'sum padahal mereka hanya manusia biasa. Klaim kebenaran tidak dapat dibenarkan karena manusia hanya memiliki kebenaran yang relatif dan hanya Allah yang tahu kebenaran absolut. Oleh sebab itu, jika ada kelompok yang merasa benar sendiri maka secara langsung mereka telah bertindak congkak merebut otoritas Allah.

Kedua, radikalisme mempersulit agama Islam yang sejatinya sambah (ringan) dengan menganggap ibadah sunnah seakan-akan wajib dan makruh seakanakan haram. Radikalisme dicirikan dengan perilaku beragama yang lebih memprioritaskan persoalan-persoalan sekunder dan mengesampingkan yang primer. Contoh-contohnya adalah fenomena memanjangkan jenggot dan meninggikan celana di atas mata kaki.
Umat Islam seyogyanya memprioritaskan kewajiban ketimbang hal-hal sunnah yang sepele. Sudahkah zakat menyelesaikan problem kemiskinan umat? Sudahkah shalat menjauhkan kita dari berbuat kemungkaran dan kekacauan sosial? Dan sudahkah haji menciptakan kesadaran kesetaraan dalam Islam? Hal-hal seperti ini seyogyanya diutamakan ketimbang hanya berkutat mengurusi jenggot dan celana.

Ketiga, kelompok radikal kebanyakan berlebihan dalam beragama yang tidak pada tempatnya. Dalam berdakwah mereka mengesampingkan metode gradual yang digunakan oleh Nabi, sehingga dakwah mereka justru membuat umat Islam yang masih awam merasa ketakutan dan keberatan. Padahal (QS. 2:85) sudah menegaskan bahwa Allah menghendaki hal-hal yang meringankan dan tidak menghendaki hal-hal yang memberatkan umat-Nya.

Keempat, kasar dalam berinteraksi, keras dalam berbicara dan emosional dalam berdakwah. Ciri-ciri dakwah seperti ini sangat bertolakbelakang dengan kesantunan dan kelembutan dakwah Nabi dalam (QS. 3:59). Dalam (QS. 6:25) Allah juga menganjurkan umat Islam supaya berdakwah dengan cara yang santun dan menghindari kata-kata kasar. Anjuran yang senada datang dari sabda Rasulullah: Sesungguhnya Allah mencintai kelembutan dalam segala hal dan kelembutan tidak masuk dalam sebuah hal kecuali membuatnya indah sedangkan 
kekerasan tidak masuk dalam sebuah hal kecuali hanya akan memperburuknya.

Kelima, kelompok radikal mudah berburuk sangka kepada orang lain di luar golongannya. Mereka senantiasa memandang orang lain hanya dari aspek negatifnya dan mengabaikan aspek positifnya. Hal ini harus dijauhi oleh umat Islam, sebab pangkal radikalisme adalah berburuk sangka kepada orang lain. Berburuk sangka adalah bentuk sikap merendahkan orang lain. Kelompok radikal sering tampak merasa suci dan menganggap kelompok lain sebagai ahli bid'ah dan sesat.

Keenam, mudah mengkafirkan orang lain yang berbeda pendapat. Di masa klasik sikap seperti ini identik dengan golongan Khawarij, kemudian di masa kontemporer identik dengan Jamaah Takfir wa al Hijrah dan kelompok-kelompok puritan. Kelompok ini mengkafirkan orang lain yang berbuat maksiat, mengkafirkan pemerintah yang menganut demokrasi, mengkafirkan rakyat yang rela terhadap penerapan demokrasi, mengkafirkan umat Islam di Indonesia yang menjunjung tradisi lokal, dan mengkafirkan semua orang yang berbeda pandangan dengan mereka sebab mereka yakin bahwa pendapat mereka adalah pendapat Allah.

Lain halnya dengan Rubaidi (2007:63) menguraikan lima ciri gerakan radikalisme Islam. Pertama, menjadikan Islam sebagai ideologi final dalam mengatur kehidupan individual dan juga politik ketata negaraan. Kedua, nilai-nilai Islam yang dianut mengadopsi sumbernya di Timur Tengah secara apa adanya tanpa mempertimbangkan perkembangan sosial dan politik ketika Al-Qura'n dan hadits hadir di muka bumi ini, dengan realitas lokal kekinian. Ketiga, karena perhatian lebih terfokus pada teks Al-Quran dan hadits, maka purifikasi ini sangat berhatihati untuk menerima segala budaya non asal Islam (budaya Timur Tengah) termasuk berhati-hati menerima tradisi lokal karena khawatir mencampuri Islam dengan bid'ah. Keempat, menolak ideologi Non-Timur Tengah termasuk ideologi Barat, seperti demokrasi, sekularisme dan liberalisasi. Sekali lagi, segala peraturan yang ditetapkan harus merujuk pada AlQuran dan hadith. Kelima, gerakan kelompok ini sering berseberangan dengan masyarakat luas termasuk pemerintah. Oleh karena itu, terkadang terjadi gesekan ideologis bahkan fisik dengan kelompok lain, termasuk pemerintah.

Setidaknya, radikalisme bisa dibedakan ke dalam dua level, yaitu level pemikiran dan level aksi atau tindakan. Dalam bidang keagamaan, fenomena radikalisme agama tercermin dari tindakan-tindakan destruktif-anarkis atas nama agama dari sekelompok orang terhadap kelompok pemeluk agama lain (eksternal) atau kelompok seagama (internal) yang berbeda dan dianggap sesat. Termasuk dalam tindakan radikalisme agama adalah aktifitas untuk 
memaksakan pendapat, keinginan, dan cita-cita keagamaan dengan jalan kekerasan. Radikalisme agama bisa menjangkiti semua pemeluk agama, tidak terkecuali di kalangan pemeluk Islam.

Sementara itu, dalam konteks kebangkitan radikalisme Islam, diyakini oleh banyak pihak sebagai ciptaan abad ke-20 di dunia Muslim, terutama di Timur Tengah, sebagai produk dari krisis identitas yang berujung pada reaksi dan resistensi terhadap Barat yang melebarkan kolonialisasi di dunia Muslim. Terpecahnya dunia Muslim ke dalam berbagai negara bangsa (nation-state) dan proyek modernisasi yang dicanangkan oleh pemerintah baru berhaluan Barat mengakibatkan umat Islam merasakan mengikisnya ikatan agama dan moral yang selama ini mereka perpegangi secara kuat. Hal ini menyebabkan munculnya gerakangerakan Islam radikal yang menyerukan kembali ke ajaran Islam yang murni sebagai jalan keluar. Tidak sampai disitu, gerakan ini melakukan perlawanan terhadap rezim yang dianggap sekuler dan menyimpang dari agama.

Selain fundamentalisme Islam, ada berbagai istilah yang dipakai para pengamat dan sarjana untuk mengidentifikasi dan menjelaskan fenomena kebangkitan Islam di dunia Muslim, antara lain: revivalisme, radikalisme, militansi, Islamisme, Islam politik (political Islam), skripturalisme, dan extrimisme. Dari berbagai istilah ini, fundamentalisme nampaknya lebih umum dipakai oleh media dan akademisi. Akan tetapi, tidak semua sarjana sepakat dengan istilah ini, karena mengandung makna pejoratif terhadap Islam.

Esposito, misalnya, mengelaborasi bahwa istilah 'funtamentalisme' diasosiasikan dengan tiga hal sebagai berikut: Pertama, mereka yang menyerukan panggilan untuk kembali ke ajaran agama yang mendasar atau pondasi agama bisa disebut sebagai kaum fundamentalis; Kedua, pemahaman dan persepsi tentang fundamentalisme sangat dipengaruhi oleh kelompok Protestan Amerika, yaitu sebuah gerakan Protestan abad ke-20 yang menekankan penafsiran Injil secara literal sebagai hal yang fundamental bagi kehidupan dan ajaran Kristen; Ketiga, istilah fundamentalisme seringkali disamakan dengan aktivisme politik, extrimisme, terorisme, dan anti-Amerika.

Oleh karena itu, Esposito (1992:8-9), menganggap istilah tersebut terlalu bermuatan re-suposisi Kristen dan stereotype Barat, serta mengisyaratkan ancaman monolitik yang tidak eksis. Karena itu, ia lebih cenderung memakai istilah 'revivalisme Islam' atau 'aktivisme Islam', yang menurutnya tidak berat sebelah dan memiliki akar dalam tradisi Islam. Selain itu, ia berargumen, "Islam mempunyai tradisi panjang dari kebangkitan (tajdid) dan reformasi (islah) yang mencakup gagasan tentang aktivisme politik dan sosial, yang dimulai pada abadabad awal Islam sampai saat ini". 


\section{Radikalisme dalam Islam}

Sejarah kekerasan dalam Islam klasik pada umumnya berkaitan dengan politik, namun akhirnya berimbas atas nama agama. Meski pembunuhan terhadap khalifah telah terjadi mulai pada masa khalifah Umar, namun gerakan kekerasan yang sistematis dan terorganisir barulah muncul setelah terjadinya perang shiffin di masa kekuasaan Ali bin Abi Talib. Hal ini ditandai dengan munculnya sebuah gerakan teologis radikal yang disebut dengan 'Khawarij'.

Secara etimologis, kata khawarij berasal dari bahasa Arab, yaitu kharaja yang berarti keluar, muncul, timbul, atau memberontak. Dari pengertian ini, kata tersebut bisa pula dimaknai sebagai golongan kaum muslimin yang keluar dari kesatuan umat Islam. Ada pula yang mengatakan bahwa pemberian nama itu disandarkan pada surat al-Nisa ayat 100 yang mengatakan: "Keluar dari rumah kepada Allah kepada Allah dan RasulNya". Dengan kata lain, golongan khawarij memandang diri mereka sebagai orang yang meninggalkan rumah atau kampung halaman untuk "berhijrah" dan mengabdikan diri kepada Allah dan RasulNya (Gholib, 2005:47).

Dalam konteks teologi Islam, Khawarij mengacu kepada kelompok atau aliran kalam yang berasal dari pengikut Ali bin Abi Thalib yang kemudian keluar dari barisan karena ketidaksetujuan pendapat terhadap keputusan Ali yang menerima arbitrase (tahkim) dengan kelompok pemberontak Mu'awiyah bin Abi Sufyan mengenai persengketaan khilafah. Menurut kelompok ini, keputusan yang diambil Ali adalah sikap salah dan hanya menguntungkan kelompok pemberontak. Kondisi inilah yang pada akhirnya melatarbelakangi sebagian barisan tentara Ali keluar meninggalkan barisan (Gholib, 2005:47).

Arbitrase terjadi dalam konteks perang shiffin antara kelompok Ali dan Mu'awiyah sebagai hasil dari pertikaian politik pasca kematian Utsman. Sebagaimana dicatat dalam sejarah, ketika Ali terpilih menjadi Khalifah, ia mendapatkan tantangan dari beberapa pemuka sahabat yang ingin menjadi Khalifah dan diantaranya ialah dari Mu'awiyah, Gubernur Damaskus. Mu'awiyah tidak mengakui Ali sebagai Khalifah seperti halnya sahabat seperti Talhah dan Zubair. Ia menuntut kepada Ali agar menghukum pembunuhpembunuh Utsman, bahkan ia menuduh Ali turut campur dalam soal pembunuhan itu. Salah seorang pemuka pemberontakpemberontak Mesir, yang datang ke Madinah dan kemudian membunuh Utsman adalah Muhammad ibn Abi Bakr, anak angkat dari Ali ibn Abi Talib. Selain itu, Ali tidak mengambil tindakan keras terhadap pemberontak-pemberontak itu, bahkan Muhammad ibn Abi Bakr ditunjuk menjadi Gubernur Mesir (Nasution, 1986:4-5). 
Pertikaian politik tersebut pada puncaknya meletus dalam perang besar antara pasukan Ali dan Mu'awiyah di Siffin. Pasukan Ali dapat mendesak tentara Mu'awiyah sehingga pasukan Mu'awiyah bersedia untuk melarikan diri. Namun tangan kanan Mu'awiyah, Amr ibn al-Ash yang terkenal sebagai orang licik, minta berdamai dengan mengangkat alQur'an ke atas.

Abl-Qurra' yang ada di pihak Ali mendesak Ali supaya menerima tawaran itu dan dengan demikian dicarilah perdamaian dengan mengadakan arbitrase (tahkim) diantara kedua pihak. Sebagai pengantara diangkat dua orang: 'Amr ibn al-Ash dari pihak Mu'awiyah dan Abu Musa al-Asy'ari dari pihak Ali. Sejarah mengatakan antara keduanya terdapat kesepakatan untuk menjatuhkan kedua pemuka sahabat yang bertentangan.

Namun, berkat kelicikan 'Amr, arbitrase ini menguntungkan pihak Mu'awiyah karena ia mengumumkan hanya menyetujui pemakzulan Ali yang telah diumumkan lebih dulu oleh alAsy'ari, dan menolak penjatuhan Mu'awiyah. Akibat arbitrase ini kedudukan Mu'awiyah naik menjadi Khalifah yang tidak resmi (Nasution, 1986:4-5).

Khawarij muncul sebagai sikap kekecewaan terhadap arbitrase yang dikemukakan sebelumnya. Sebagian barisan Ali ini beranggapan bahwa perang tersebut tidak dapat diselesaikan dengan tahkim manusia. Putusan hanya datang dari Allah dengan kembali kepada hukumhukum yang ada dalam al-Qur'an. Semboyan mereka adalah la bukma illa lillah (tidak ada hukum selain dari hukum Allah) atau la bakama illa Allab (tidak ada pengantara selain dari Allah). Salah satu pendasaran dalil mereka adalah Q.S. alMaidah: 44. Mereka memandang bahwa 'Ali, Mu'awiyah, Amr ibn al-As, Abu Musa al-Asy'ari dan lainnya yang menerima arbitrase sebagai kafir karena tidak kembali ke al-Qur'an dalam menyelesaikan pertikaian tersebut.

Persoalan takfir ini menjadi awal persoalan teologis dalam Islam dimana Khawarij sebagai pelopor awal. Karena memandang pemuka-pemuka sahabat yang tersebut kafir, ini berarti mereka diklaim telah keluar dari Islam (murtad) dan halal darahnya untuk dibunuh. Kaum Khawarij mengambil keputusan untuk membunuh keempat pemuka sahabat tersebut, namun hanya Ali yang berhasil dibunuh. Dari sinilah timbul masalah perbuatan dosa besar: apakah orang yang memutuskan masalah dengan tidak kembali ke al-Qur'an masih Islam ataukah sudah keluar dari Islam dan menjadi kafir? Dalam kaitan ini, Khawarij berpegang pada posisi bahwa pembuat dosa besar sudah bukan Muslim lagi, namun telah menjadi kafir.

Radikalisme Khawarij sebagai pemberontak telah dicatat dalam sejarah. Tidak hanya di masa Ali, Khawarij meneruskan perlawanan berkelanjutan terhadap kekuasaan Islam resmi, baik di 
zaman Dinasti Bani Umayah maupun di zaman Dinasti Bani Abbas. Pemegangpemegang kekuasaan yang ada pada waktu itu mereka anggap kafir dan telah menyeleweng dari Islam dan karena itu mesti dilawan dan dijatuhkan. Oleh karena itu, mereka memilih imam sendiri dan membentuk pemerintahan kaum Khawarij (Nasution, 1996:124).

Radikalisme gerakan ini bukan saja pada sisi pemahaman tetapi juga pada sisi aksi. Khawarij memahami ajaran-ajaran Islam secara harfiyah sebagaimana terdapat dalam al-Qur'an dan Hadis dan mereka merasa wajib melaksanakannya tanpa melakukan penafsiran lebih jauh. Bahkan beberapa sekte Khawarij bersikap lebih radikal. Al-Azariqah, misalnya, berpendapat bahwa pelaku dosa besar tidak lagi disebut kafir, tetapi muysrik, yaitu dosa besar yang dalam Islam sudah tidak terampuni lagi. Bahkan istilah kafir dan musyrik juga dialamatkan pada semua orang yang tidak sefaham dengan mereka, bahkan juga terhadap orang yang sefaham tetapi tidak mau hijrah ke daerah mereka.

Sikap fanatisme yang berlebihan dalam pemahaman menjustifikasi aksi- aksi kekerasan Khawarij. Mereka misalnya menganggap penentang mereka sebagai Dar al-Harb, karenanya di daerah tersebut boleh membunuh termasuk anak-anak, wanita dan tawanan (Gholib, 2005:52). Karena itu tidaklah heran jika kelompok Khawarij terkenal karena kekejamannya melalui aksi-aksi kekerasan, teror dan pembunuhan terhadap penentang- penentangnya. Dalam kaitan ini, Azra (1996:141) menyebut aksi pembunuhan Khawarij sebagai isti'rad (eksekusi keagamaan) ketimbang jihad.

Menurut beberapa penulis, watak keras kaum Khawarij dibentuk oleh latar belakang mereka yang pada umumnya berasal dari orang-orang Arab Badawi. Hidup di padang pasir yang serba tandus membuat mereka bersifat sederhana dalam cara hidup dan pemikiran, tetapi keras hati serta berani, dan bersikap merdeka, tidak bergantung pada orang lain (Nasution, 1986:13).

Dengan latar belakang ini, kaum Khawarij dikenal sebagai kelompok yang ekstrim dan puritan dalam beragama, dan memiliki idealisme tentang persamaan hak dalam gerakannya (Ghazali, 2003:82-83). Dalam bahasa Nasution (1986:13), kaum ini memiliki iman yang tebal, namun sempit pemikirannya dan fanatik buta. Akibatnya, mereka tidak bisa mentolerir penyimpangan-penyimpangan terhadap ajaran Islam menurut versi mereka, meskipun hanya penyimpangan dalam bentuk kecil (Nasution, 1986:13).

\section{Islam dan Radikalisme}

Sebagai sebuah konsep, sikap Islam anti terorisme hadir dalam rangka untuk mewujudkan masyarakat yang damai, tanpa terorisme. Dalam prosesnya, nilainilai Islam dapat ditranformasikan dengan berbagai macam bentuk, diantaranya adalah melalui lembaga pendidikan sebagai locus transfer of knowlige. 
Institusi pendidikan Islam mempunyai peranan yang sangat strategis untuk melakukan tranformasi nilai-nilai anti teorisme dalam rangka mewujudkan peserta didik yang anti terhadap radikalisme. Konstruksi masyarakat yang tanpa radikalisme, dapat diwujudkan dengan penanaman nilai toleransi, pluralism, dan anti kekerasan.

Setidaknya ada 4 (empat) isu penting yang dipandang sebagai dasar Islam dalam menolak radikalisme ini, yaitu : Pertama, kesatuan dalam aspek ke'Tuhanan dan pesan-Nya (wahyu); Kedua, kesatuan kenabian; Ketiga, tidak ada paksaan dalam beragama; dan Keempat, pengakuan terhadap eksistensi agama lain. Semua yang demikian disebut secara normatif, karena sudah merupakan ketetapan Tuhan. Masing-masing klasifikasi didukung oleh teks (wahyu), kendati satu ayat dapat saja berfungsi untuk justifikasi yang lain (Rahman, 2001: 31-40).

Dari aspek kesatuan keTuhanan, Islam mendasarkan pandangannya dari alQur'an surat an-Nisa': 131:

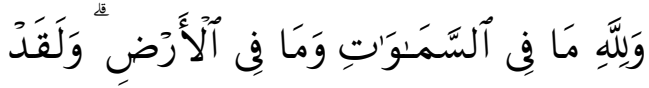

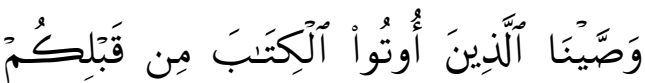

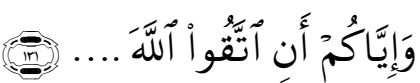

Dan milike. Allab-lah apa yang ada di langit dan apa yang ada di bumi, dan sungguh, Kami telah memerintabkan kepada orang yang diberi kitab suci sebelum kamu dan juga kepadamu agar bertakwa kepada Allah.
Surat Ali Tmran: 64:

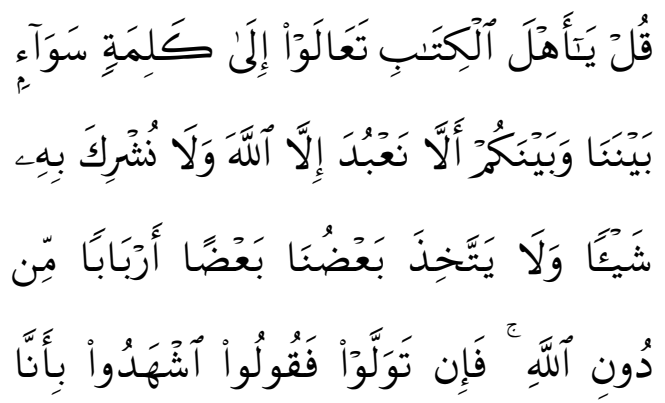

$$
\text { مُسَلمَوبَتَ }
$$

Katakanlah (Muhammad), Wabai Ablu-lKitab! Marilah kita menuju kepada satu kalimat (pegangan) yang sama antara kami dan kamu, babwa kita tidak menyembah selain Allah dan kita tidak mempersekutukan-Nya dengan sesuatupun, dan babwa kita tidak menjadikan satu sama lain Tuhan-Tuban selain Allah. Jika mereka berpaling maka katakanlab (kepada mereka), 'Saksikanlah, bahwa kami adalab orang Muslim.

Dari aspek kesatuan pesan keTuhanan (wahyu) dapat dilihat dalam surat an-Nisa' 163

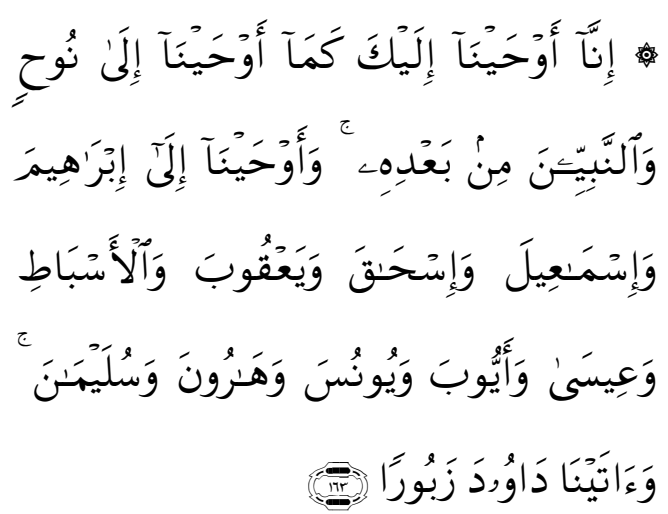

Sesunggubnya Kami mewabyukan kepadamu (Mubammad) sebagaimana Kami telah mewabyukan kepada Nub dan nabi-nabi setelabnya, dan Kami telab mewabyukan (pula) kepada Ibrabim, Isma'il, Ishaq, Ya'qub, dan anak cucunya; Isa, Ayyub, Yunus, Harun dan Sulaiman. Dan kami 
telah memberikan Kitab Zabur kepada Dawnd.

Dari aspek kesatuan kenabian, alFaruqi mendasarkan pandangannya dari al-Qur'an surat al-Anbiya': 73:

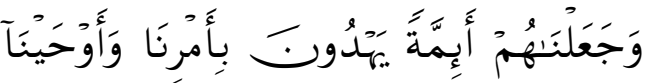

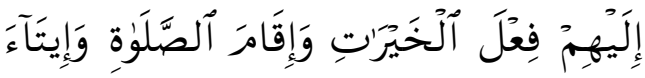

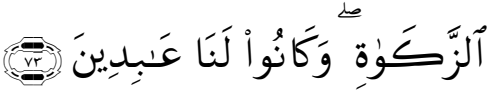

"Dan Kami menjadikan mereka itu sebagai pemimpin-pemimpin yang memberi pentunjuk dengan perintah Kami, dan Kami wabyukan kepada mereka agar berbuat kebaikan, melaksanakan salat dan menunaikan zakat, dan banya kepada Kami mereka menyembab".

Kemudian surat Ali Tmran: 84;

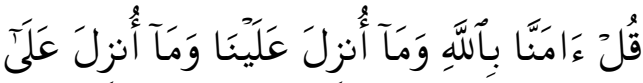

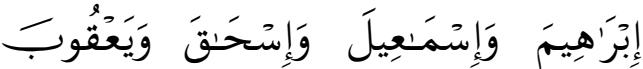

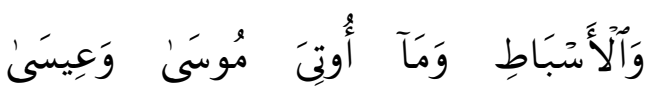

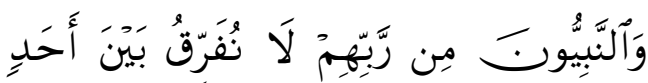

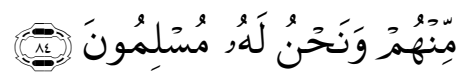

"Katakanlab (Muhammad), Kami beriman kepada Allah dan kepada apa yang diturunkan kepada kami dan yang diturunkan kepada Ibrabim, Isma'Il, Ishaq,Ya'qub dan anak cucunya, dan apa yang diberikan kepada Musa, Isa dan para nabi dari Tuban mereka. Kami tidak membeda-bedakan seorang pun di antara mereka dan hanya kepada-Nya kami berserah diri".
Pandangan Islam yang terkait dengan kebebasan menganut agama didasarkan kepada al-Qur'an surat al-Baqarab: 256;

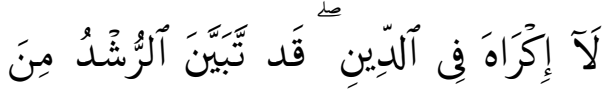

$$
\begin{aligned}
& \text { آلَخَّ }
\end{aligned}
$$

Tidak ada paksaan dalam (menganut) agama (Islam), sesunggubnya telab jelas (perbedaan) antara jalan yang benar dengan jalan yang sesat.....

Terakhir adalah mengenai pengakuan al-Qur'an surat al-Maidah: 69 akan eksistensi agama-agama lain;

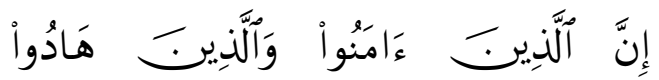

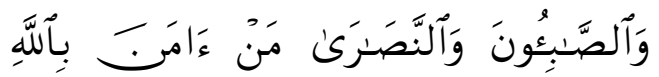

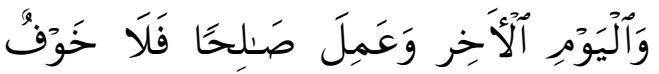

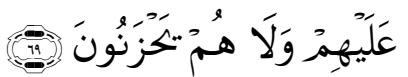

Sesunggubnya orang-orang yang beriman, orang-orang Yabudi, Sabiin, dan orang-orang Nasrani, barang siapa beriman kepada Allah, kepada hari kemudian dan berbuat kebajikan, maka tidak ada rasa khawatir padanya dan mereka tidak bersedib hati".

Informasi lain dalam al-Qur'an adalah :

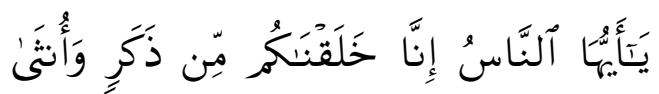

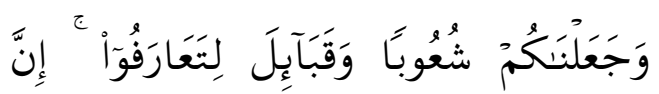

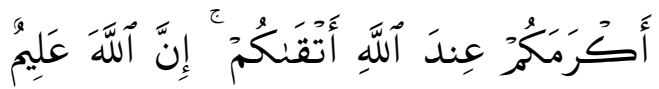

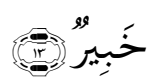

"Hai manusia, Sesunggubnya Kami menciptakan kamu dari seorang laki-laki dan seorang perempuan dan menjadikan 
kamu berbangsa - bangsa dan bersuku-suku supaya kamu saling kenal-mengenal. Sesunggubnya orang yang paling mulia diantara kamu disisi Allah ialah orang yang paling taqwa diantara kamu. Sesunggubnya Allah Maha mengetabui lagi Maha Mengenal (Al-bujurat: 13).

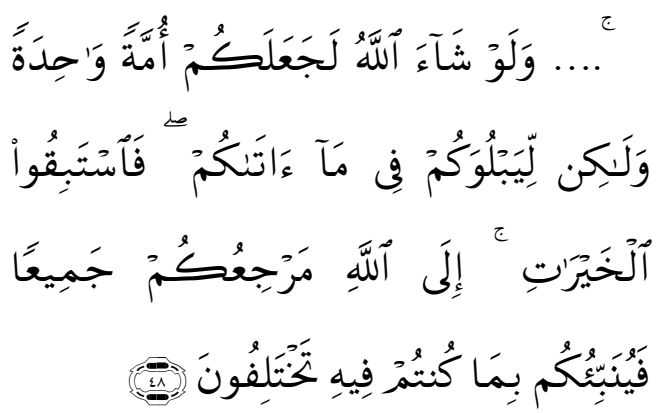

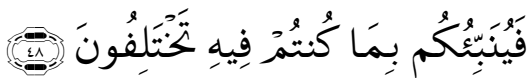

Sekiranya Allah menghendaki, niscaya Ia akan menjadikan kamu (sekalian) satu umat, tetapi Ia hendak menguji kamu atas pemberian-Nya. Maka berlombalah kamu dalam kebajikan. Kepada Allah tempat kamu kembali, maka ditunjukkan kepadamu apa yang kamu perselisibkan (QS. Al-Ma’idah: 48).

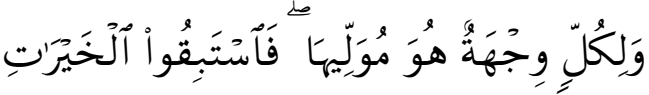

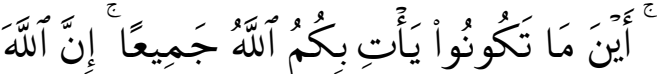

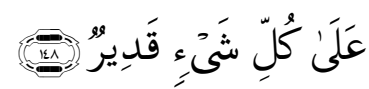

Bagi setiap umat ada kiblatnya yang ia menghadap kepada-Nya; maka berlombalah kamu dalam mengejar kebaikan. Di manapun kamu berada, Allah akan menghimpun kamu karena Allah berkuasa atas segalanya (QS. Al-Baqarah: 148)

Beberapa ayat diatas, memberikan implikasi bahwa :

Pertama, bahwa Allah menjadikan umat ini berbeda, baik dari segi jenis kelamin, bangsa, dan suku. Sehingga perbedaan dan kemajmukan atau pluralitas tersebut menjadi sebah keniscayaa.
Kedua, bahwa setiap masyarakat atau umat memiliki aturan dan jalannya sendiri. Yang pada proses selanjutnya, setiap masyarakat harus yakin terhadap ajaran agamanya sendiri, karena Allah pasti akan "menguji atas apa yang telah Ia berikan" liyabluwakum fìmâ âtâkum.

Ketiga, bahwa setiap masyarakat agama harus berlomba-lomba dalam kebajikan $\mathrm{Fa}$ 'stabiqûu'l-khayrât.

Keempat, bahwa setiap masyarakat agama harus menghormati perbedaan yang memisahkan mereka. Tidak dianjurkan untuk menghakimi keyakinan agama lain, karena di Hari Akhir nanti, Allah akan menunjukkan "apa yang diperselisihkan"

\section{Penutup}

Bagaimanapun radikalime merupakan benih awal, bagi munculnya teror. Dan ini tebntu merupakan masalah masyarakat (sosial problem). Meskipun, secara definitive sampai detik ini masih mengalami kontroversi yang luar biasa. Namun, berpijak pada varian definisi yang penulis temukan sebagaimana telah terurai di atas, setidaknya memberikan gambaran bagaimana indikasi radikalisme cukup membahayakan bagi kelangsungan hidup umat manusia. Meskipun dirasa sangat tidak memungkinkan sampai pada sebuah rumusan definisi radikalisme secara baku yang diterima (legitimit) pada semua kalangan. 


\section{DAFTAR PUSTAKA}

Azra., Azyumardi, 1996., Pergolakan Politik Islam: Dari Fundamentalisme, Modernisme Hingga Post-Modernisme. Jakarta: Penerbit Paramadina

Cobuild, Collin., 2001., English Dictionary for Advanced Learners. UK: Harper Collins Publisher.

Departemen Pendidikan Nasional, 2002., Kamus Besar Bahasa Indonesia, Edisi III (Cet. II; Jakarta Balai Pustaka,), 919

Echol., John M. dan Shadily., Hassan., 1996., Kamus Inggris Indonesia (Cet. XXV; Jakarta: Gramedia

Effendy., Bachtiar, 1998., Radikalisme: Sebuah Pengantar., Jakarta: PPIM. IAIN,

Esposito, John L., 1992., The Islamic Threat: Myth or Reality., New York: Oxford University Press, 1992

Ghazali., Adeng Muchtar, 2003., Perkembangan Ilmu Kalam dari Klasike bingga Modern. Bandung: Pustaka Setia

Gholib., Achmad., 2005., Teologi dalam Perspektif Islam., Jakarta: UIN Jakarta Press

Hasani., Ismail dan Naipospos., Bonar Tigor, 2010., Radikalisme Agama di Jabodetabek \& Jawa Barat: Implikasinya terhadap Jaminan Kebebasan Beragama/Berkeyakinan. Jakarta: Pustaka Masyarakat Setara

Hornby., A.S., 2000, Oxford Advenced, Dictionary of current English, UK: Oxford university press

Jamhari dan Jahroni, Jajang (penyuting), 2004., Gerakan Salaf Radikal di Indonesia, Jakarta: PT Raja Grafndo Persada.
Kartodirdjo., Sartono, Ratu Adil (Jakarta: Sinar Harapan, 1985), 38.

Masduqi, Irwan., 2012., "Deradikalisasi Pendidikan Islam Berbasis Khazanah Pesantren" dalam Jurnal Pendidikan Islam, No 2 Vol 1, 2012, 3.

Muchith., M. Saekan, 2016., "Radikalisme dalam Dunia Pendidikan", dalam Jurnal Addin Ilmu Sosial dan Keagamaan, Vol. 10, No.1, Februari (Kudus: STAIN Kudus, 2016), 171

M. Nuh., Nuhrison, 2009., "Faktor-Faktor Penyebab Munculnya Faham/ Gerakan Islam Radikal di Indonesi" dalam Jurnal Harmoni, Jurnal Multikultural \& Multireligius, Vol VIII Juli-September

Nasution, Harun., 1986., Teologi Islam: Aliran-aliran Sejarab Analisa Perbandingan. Jakarta: UI Press , 1996., Islam Rasional: Gagasan dan Pemikiran Prof. Dr. Harun Nasution., Bandung: Mizan.

Qardhawi, Yusuf., 2004., al-Thtarruf alDini, Kairo: Maktabah Wahbah ., 2009., Islam Radikal. (H. Murtadho, Trans.) Pajang Laweyan: Era Adicitra Intermedia.

Rahman., Budhy Munawar., 2001., Islam Pluralis, Jakarta : Paramadina

Rubaidi, A., 2007., Radikalisme Islam, Nabdatul Ulama Masa depan Moderatisme Islam di Indonesia, Yogyakarta: Logung Pustaka

Suprihatiningsih, 2012., "Spiritualitas Gerakan Radikalisme". dalam Jurnal Ilmu Dakwah, 